\title{
A STUDY ON CONSUMER PERCEPTION TOWARDS ONLINE TICKETING SYSTEMS
}

\section{Gowtham Aashirwad Kumar}

Assistant Professor \& Research Scholar, Department of Management Studies, Bharath Institute of Higher Education and Research (BIHER), India

\section{Dr A Ravikumar}

Associate Professor \& Research Supervisor, Department of THM, Bharath Institute of Higher Education and Research (BIHER), India

\begin{abstract}
This paper offers a record of an assessment that investigated peoples" perspective on net essentially based acquiring tickets (e-ticketing) similarly as why a few of people use this office simultaneously as a rare kinds of people that don't use it hold close the standard system to deal with their issues. Besides, factors, as an example, what expel haziness from peoples" energy and hesitance to use web work environments are in like manner broke down. The aftereffect of this investigation showed a totally organized shape which will be utilized by method makers and endeavor dares to know the dynamic associations among estimations of saw danger, client dependability, cost, nature and sureness. Moreover, this examination thought roughly how value prevalence and web security could be utilized to perceive the consumers" insight. Be that since it'd, further investigations is required to require a gander at those factors in Malaysia with more noteworthy models before theory are often made. Also, it's moreover fundamental to review consumers" purchasing conduct in choosing the choice to use the online as a techniques for purchasing on the online instead of the standard way.
\end{abstract}

Keywords: Online Ticketing Systems, e-ticketing, Tourism, Hotel Management, electronic shopping

Cite this Article: Gowtham Aashirwad Kumar and Dr A Ravikumar, A Study on Consumer Perception Towards Online Ticketing Systems, International Journal of Advanced Research in Engineering and Technology (IJARET), 11 (1), 2020, pp 110-115.

http://iaeme.com/Home/issue/IJARET?Volume=11\&Issue=1

\section{INTRODUCTION}

Generally, electronic shopping incorporates rummaging through measurements and doing physical games that give the clients the info that help them to land at an informed inclination and direct business. On the opposite hand, web shopping addresses system wont to exchange measurements and buy article or organizations electronically. The exponential improvement 
within the amount of individuals executing venture electronically is proof that the thought has transformed showcasing strategy by companies and endeavors. As referenced previously, the movement venture division has been a far reaching beneficiary of this shock as found within the improvement recorded within the rise of traveling work environments inside a really speedy time span. Most of those organizations inside the best current decade have found out site to confer and empty the pickle to accomplish their target advertise yet there are so far numerous people that hold close the standard methodology for gaining tickets due to such a huge scope of components. a touch of the clients discover this framework exceptionally risky, or they'll most presumably be unable to use internet well, on explicit hands, they're going to nevermore be capable adequate which is that the region artfulness at the utilization of PC structure accept a big activity in affecting the customer.

\section{REVIEW OF LITERATURE}

Ahasanul et al., (2009) ${ }^{\mathbf{1}}$ The web empowers organizations to introduce assortments of items and administrations, yet because of the idea of online market, basic leadership in buying things on the web. Therefore, organizations are clearly befuddled about what customers really prefer to purchase on the web. Regardless of an impressive help from the legislature and advertisers to support and push the individuals to utilize the web for business, web based shopping rate in Malaysia has diminished from 5\% of absolute web clients in 2000 to just 3\% in 2002.

Caral-Mafe et al., (2009) ${ }^{2}$ The timeframe evident danger infers the individual's rundown conviction roughly a few of possibly negative impacts from his/her decision.

Selling through the web is popping into an example for many expert associations. The supporter buy desire toward electronic absolutely buying depends on their affirmation of the online as a movement channel. Shim et al recommend that customers' airs toward on internet getting are hooked in to change organizations, comfort, unmistakable enjoy and stock. Kim states that online buyer steadfastness is arranged underneath after-offers organization, purchase final product and charge connecting with incredible, thing certainties, supporter support, site plan, thing drawing in extraordinary, portion technique, website records and check in convenience.

Famet al explicit that the determinants of believe during a web space are issue to consistency, deliberateness, capacity, transference, and considerable incredible and instinct. In trades, acknowledge as valid with is an important force in improving exchange.

\section{OBJECTIVES OF STUDY}

\subsection{Primary Objectives}

To study about the consumer perception towards online ticketing systems.

\subsection{Secondary Objectives}

- To perceive the perceptions and collection of musings of web customers determined to possess on line Travel moreover, value ticket booking.

- To observe the customers' undeniable significance of credits perceived with on line Travel passages.

- To Measure the essentialness of Click and Mortar Model contrary to Only Web Presence. 


\section{NEED FOR STUDY}

To know consumer perception towards online ticketing systems.

\subsection{Scope for Study}

Detached Presence of Online travel organizations would result to Greater customer reliability.

\section{RESEARCH METHODOLOGY}

Research may be a brilliant guarantee to the rear and forth movement store of limit. it's the experience for truth with the assistance of watch insight, evaluation and fundamentals. The mission for records by procedures for targets and effective methodology of going over decision to an issue is explore.

\subsection{Research Design}

Sensible research game plan adjusted into utilized appropriate at now . It understands a goliath a bit of selling Research. The arrangement is to supply a cautious photograph of tangible segments of the publicizing condition.

\subsection{Sample Size}

An example size alludes to the scope of devices to be chosen from the masses to establish an example. 100 respondents were chosen as tests for review.

\subsection{Sampling Technique}

The scientist as utilized probabilistic deliberate inspecting. In this technique the components are chosen from the people at a uniform interim that is estimated in time, request or space.

\section{LIMITATIONS OF STUDY}

Sensible research game plan adjusted into utilized appropriate at now. It understands a goliath a bit of selling Research. The arrangement is to supply a cautious photograph of tangible segments of the publicizing condition.

\section{RESEARCH METHODOLOGY}

Basic consistent with the overall tendency of any standard advancing considers undertaking may be a ound checks plan. A middle of the road assessments affiliation has the attributes of issue definition, unequivocal methodologies of records assortment and assessment, time required for research adventure and check of costs to be acquired. The limitation of an examinations design is to ensure that the require truths are amassed in light of the very fact that it need to be and financially. The Research bunch utilized in the examine is plain assessments plan. The Research setup applied within the test is luring investigation plan.

\subsection{Area of Study}

Area of analyze is selling the officials; the examination is knowing the Social media for global promoting. the instance size is 100 .

\subsection{Data Sources}

Primary Data: Central facts is that the fundamental insights amassed by methodologies for the analyst direct. It is amassed just considering reality that by systems for control inspect. 
Secondary Data: Optional certainties is that the records which is starting at now accessible in distributed or unpublished structure. The optional store utilized forth is appraisal is affiliation profile, scope, need, overview of forming.

\section{DATA ANALYSIS AND INTERPRETATION}

Table 1: Lead towards Online Ticket

\begin{tabular}{|c|l|c|c|}
\hline S.NO & PARTICULARS & RESPONDENTS & PERCENTAGE \\
\hline 1 & Online Travel Agency. & 60 & $60 \%$ \\
\hline 2 & Airline Websites & 30 & $30 \%$ \\
\hline 3 & Local Agents & 5 & $5 \%$ \\
\hline 4 & Others & 5 & $5 \%$ \\
\hline & Total & 100 & $100 \%$ \\
\hline
\end{tabular}

\section{Inference}

Most of the people book tickets through online travel agency. 30\% of people books ticket through Airline websites. And only 10\% of books ticket through each $5 \%$ of local agents and others.

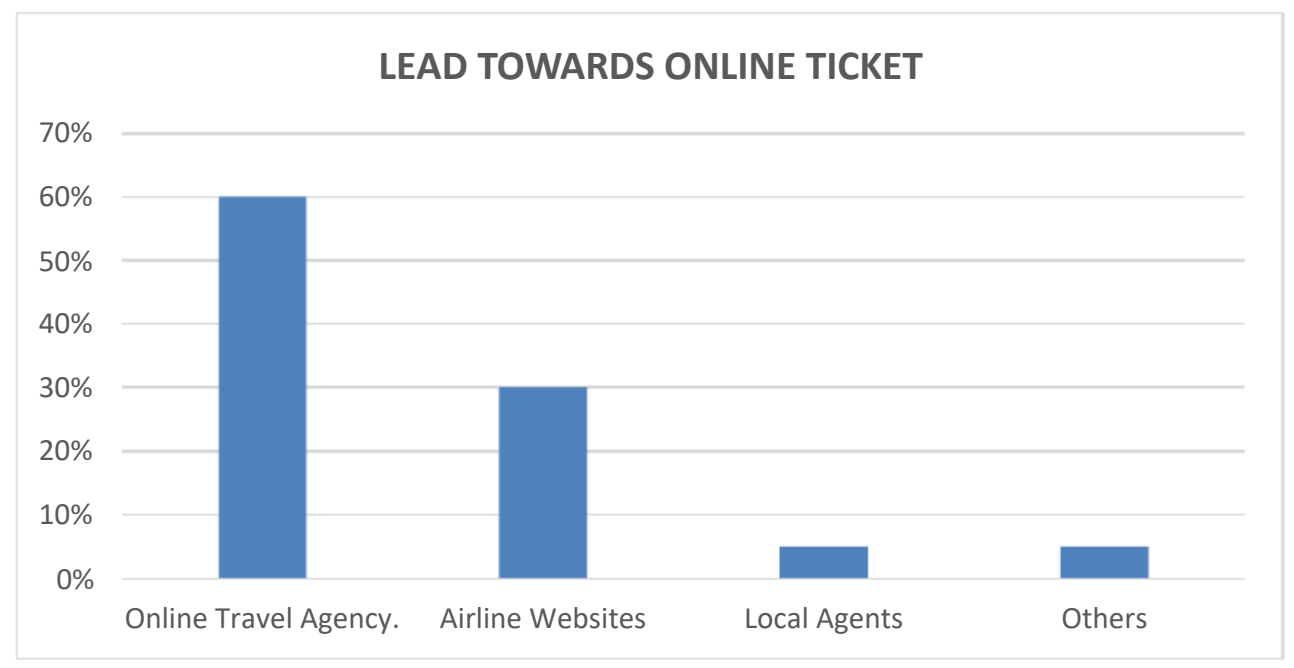

Figure 1

Table 2: When you Examined for Information, from During which U Lean Nearer to Shopping Your Airline Ticket

\begin{tabular}{|c|l|c|c|}
\hline S.NO & \multicolumn{1}{|c|}{ PARTICULARS } & RESPONDENTS & PERCENTAGE \\
\hline 1 & Online Travel Portals & 40 & $40 \%$ \\
\hline 2 & Airline Websites & 30 & $30 \%$ \\
\hline 3 & Local Agents & 20 & $20 \%$ \\
\hline 4 & Others & 10 & $10 \%$ \\
\hline & Total & 100 & $100 \%$ \\
\hline
\end{tabular}

\section{Inference}

Most of the people use online travel portal. $30 \%$ use airline websites. $20 \%$ use local agents and only $10 \%$ use other sources. 


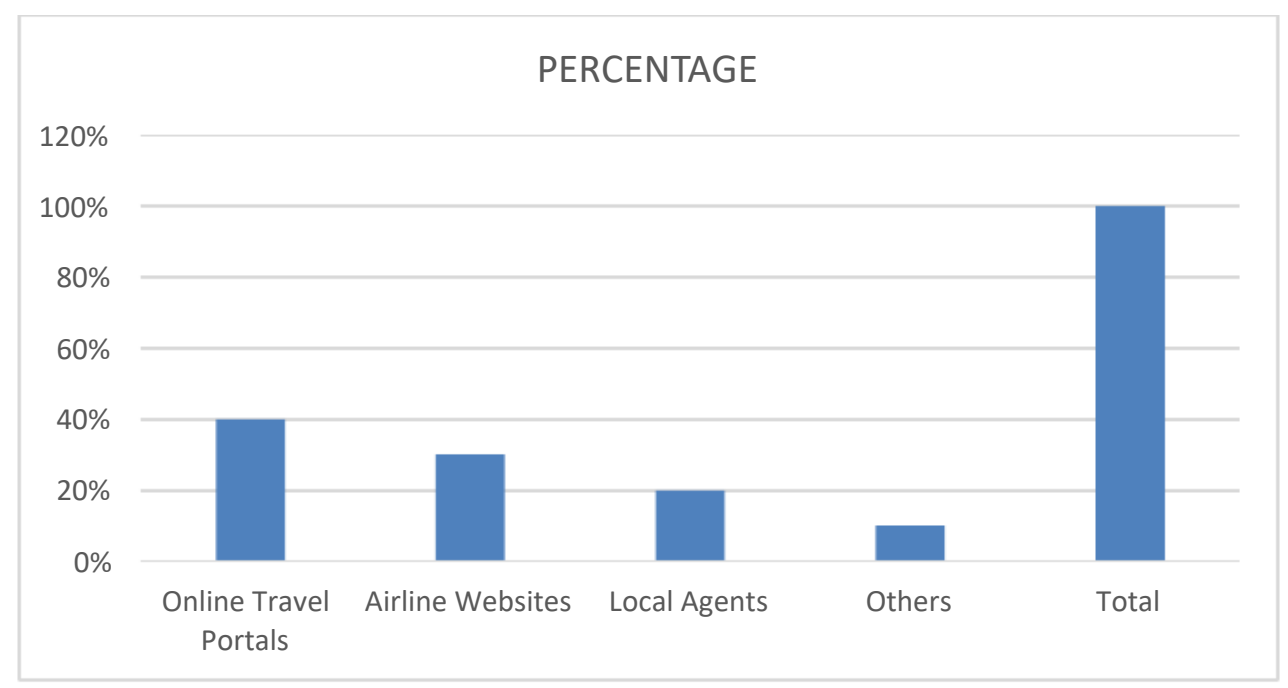

Figure 2

\section{CHI SQUARE TEST}

Table 3: Lead towards Online Ticket

\begin{tabular}{|c|c|}
\hline 60 & 30 \\
\hline 05 & 05 \\
\hline
\end{tabular}

\begin{tabular}{|c|c|c|c|c|}
\hline $\mathbf{O}$ & $\mathbf{E}$ & $\mathbf{( O - E )}$ & $(\mathbf{O}-\mathbf{E})^{2}$ & $(\mathbf{O}-\mathbf{E})^{2} / \mathbf{E}$ \\
\hline 60 & 58.5 & 1.5 & 2.25 & 0.0385 \\
\hline 30 & 31.5 & -1.5 & 2.25 & 0.0714 \\
\hline 05 & 6.5 & -1.5 & 2.25 & 0.3462 \\
\hline 05 & 3.5 & 1.5 & 2.25 & 0.6429 \\
\hline & & & Total & 1.09896 \\
\hline
\end{tabular}

\section{Null Hypothesis}

There is no significant difference between people choosing platform in booking online ticket.

\section{Alternative Hypothesis}

There is significant difference between people choosing platform in booking online ticket.

Chi Square Test $=(\mathrm{O}-\mathrm{E})^{2} / \mathrm{E}$

Chi Square Test $=1.0989$

Degrees of Freedom

$\mathrm{V}=[\mathrm{r}-1][\mathrm{c}-1]$

$\mathrm{V}=[2-1][2-1]$

$\mathrm{V}=1 \mathrm{X} 1$

$\mathrm{V}=1$

Table Value [T.V] $=3.84$

Calculated Value [C.V] $=1.0989$

Therefore, Calculated Value (C.V) < Table Value (T.V) 


\section{FINDINGS AND SUGGESTIONS}

- Most of the people book ticket through online agency.

- Most of the people use online travel agency.

\section{CONCLUSION}

The online visit shopping conduct depends on a person's characteristics and characteristics. In on-line purchases, customers may detect distrustful about the site's unflinching extraordinary and realness. In making countries, the detachment of legitimate system help for on-line venture sites escalates the nonattendance of trust.

\section{REFERENCES}

[1] Bonn M. A. Furr, L. H and Susskind, A. M.( 1998 ) Using the Internet as a Pleasure Travel Planning Tool: An Examination of the Socio-Demographic and Behavioral Characteristics among Internet Users And Non-Users. Journal of Hospitality and Tourism Research 22 (3): $303-317$.

[2] Citrin, A. V., Sprott, D. E .and Silverman, S. N ( 2000 ) Adoption of Internet shopping: The Role of Consumer Innovativeness. Industrial Management \& Data Systems 100 (7): $294-300$.

[3] Dr. V. Maheswari, A Study on Consumer Perception and Satisfaction of Water Purifier in Kumbakonam Town, Journal of Management, 6(2), 2019, pp. 240-246

[4] Dr .V. Antony Joe Raja, A Study on Consumer Perception in Facilities Management Among the Middle Income Public in India for Various Analytical Factors Applied in the Strategic Management, International Journal of Intellectual Property Rights (IJIPR), 5(1), 2014, pp. 1-17

[5] P. Karthikeyan, P. Arul Murugan, N. Devi, An Empirical Analysis on Consumer Perception Towards Branded Trousers in Coimbatore City, International Journal of Management (IJM), 4(1), 2013, pp. 74-84

[6] Pritam Chattopadhyay and Dr. RuchiJain, An Empirical Study of Consumer Perception and Loyalty as Factors of The Selection of Private Label Brands at Select Retail Stores of Pune with Special Reference to Organized Retailing, International Journal of Mechanical Engineering and Technology, 9(4), 2018, pp. 643-652

[7] M. Farook Hussain and Dr. R. Khader Mohideen. An Empirical Study on Organized Retail Outlet and Consumer Perception towards Retail Stores in Tiruchirappalli City. International Journal of Management, 7(2), 2016, pp. 489-496

[8] Murthy, B. G. K., Dr. Satish Babu, A and Dr. Nagaraju, B.Consumer Perception Towards Mobile Value Added Services. International Journal of Management (IJM), 6(9), 2015, pp. 102-109

[9] J. Chandrasekaran and Dr. M. Raja, Consumer Perception Towards Shopping Mall with Reference to Tiruchirappalli District in Tamil Nadu, Journal of Management, 5(4), 2018, pp. $138-137$

[10] Jyotishman Das, Consumer Perception Towards Online Food Ordering and Delivery Services: An Empirical Study, Journal of Management, 5(5), 2018, pp. 155-163

[11] Dr. Rajesh Kanthe, Vaishali Pramod Pawar, Rajendra Mohite, Sale of over the Counter (OTC) Drugs Via Post Offices-A Consumer Perception, International Journal of Advanced Research in Management (IJARM), 3(2), 2012, pp. 63-68 